\title{
Differences in Early Childhood Environmental Rating Scale Scores in Collaborative and Non-Collaborative West Virginia Pre-K Classrooms located in Child Care Facilities
}

Jessica S. Day

West Virginia University

Follow this and additional works at: https://researchrepository.wvu.edu/etd

\section{Recommended Citation}

Day, Jessica S., "Differences in Early Childhood Environmental Rating Scale Scores in Collaborative and Non-Collaborative West Virginia Pre-K Classrooms located in Child Care Facilities" (2013). Graduate Theses, Dissertations, and Problem Reports. 625.

https://researchrepository.wvu.edu/etd/625

This Thesis is protected by copyright and/or related rights. It has been brought to you by the The Research Repository @ WVU with permission from the rights-holder(s). You are free to use this Thesis in any way that is permitted by the copyright and related rights legislation that applies to your use. For other uses you must obtain permission from the rights-holder(s) directly, unless additional rights are indicated by a Creative Commons license in the record and/ or on the work itself. This Thesis has been accepted for inclusion in WVU Graduate Theses, Dissertations, and Problem Reports collection by an authorized administrator of The Research Repository @ WVU. For more information, please contact researchrepository@mail.wvu.edu. 
Differences in Early Childhood Environmental Rating Scale Scores in Collaborative and Non-Collaborative West Virginia Pre-K Classrooms located in Child Care Facilities

\author{
Jessica S. Day \\ Thesis submitted to the \\ College of Human Resources and Education \\ at West Virginia University \\ in partial fulfillment of the requirements for the degree of \\ Master of Arts \\ in Educational Psychology \\ with an emphasis in Child Development and Family Studies \\ Barbara G. Warash, Ed. D., Chair \\ Suzanne Hartman, Ph. D. \\ Reagan Curtis, Ph.D.
}

Department of Technology, Learning, and Culture

Morgantown, West Virginia

2013

Keywords: pre-k collaborative; pre-k non-collaborative; environmental rating scale; structural quality; process quality; Ecological Systems Theory

Copyright 2013 Jessica S. Day 


\begin{abstract}
Differences in Early Childhood Environmental Rating Scale Scores in Collaborative and Non-Collaborative West Virginia Pre-K Classrooms located in

Child Care Facilities

Jessica S. Day

Quality of pre-k collaborative and non-collaborative classrooms was investigated for differences in environmental quality between the two types of classrooms. Data was collected through the West Virginia Department of Health and Human Resources grant titled, “Quality Rating and Improvement for West Virginia Child Care.” Quality was measured using the Early Childhood Environmental Rating Scale-Revised (ECERS-R), which has 43 items across seven subscales: Space and Furnishings, Personal Care Routines, Language-Reasoning, Activities, Interaction, Program Structure, and Parents and Staff. Thirty-six pre-k collaborative programs participated and 136 non-collaborative programs participated in the study. Non-collaborative pre-k classrooms had lower mean scores on all subscales except Personal Care Routines. There were significant differences between the two types of classrooms on three out of the seven subscales: Space and Furnishings, Activities, and Program Structure. There was also a significant difference between collaborative and non-collaborative classrooms based on their overall ECERS-R scores.
\end{abstract}




\section{Acknowledgement}

I would like to express my highest gratitude to my advisor and committee chairperson, Dr. Barbara Warash. Her mentoring, support, encouragement, and guidance attributed to the completion of my Master's level research and education. Along with my committee chairperson, I would like to thank fellow committee members, Dr. Reagan Curtis and Dr. Suzanne Hartman for their direction and assistance during the construction of my thesis. I would also like to thank Keri Law for her continued guidance and knowledge throughout my graduate level education and for her support through my research of this study. Finally, I would like to thank my family and friends who have given me the support and confidence to succeed in my education and in life. 


\section{Table of Contents}

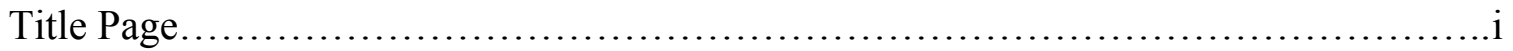

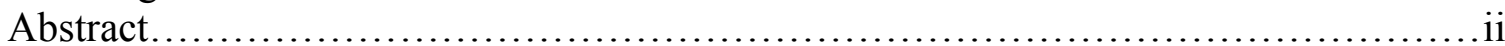

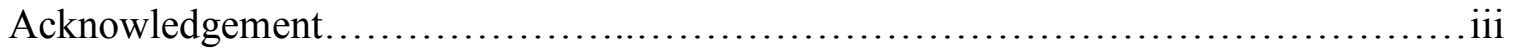

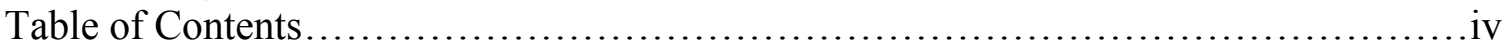

CHAPTER I

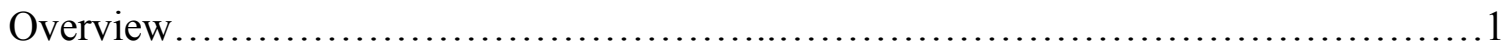

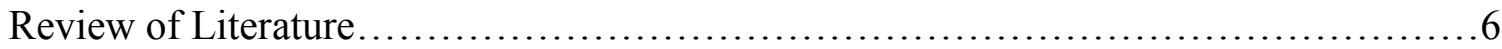

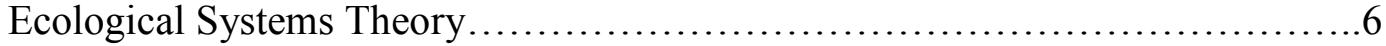

National Trends in Early Childhood.......................................... 8

Structural and Process Quality........................................... 9

Aspects of Structural Quality......................................9

Teacher Education........................................ 10

Teacher Wage..............................................13

Teacher-child Ratio.......................................... 14

Process Quality..................................................... 14

Measuring Environmental Quality...............................18

Observation Record of the Caregiving Environment.............19

Classroom Practices Inventory.............................20

Classroom Assessment Scoring System.......................21

Early Childhood Environmental Rating Scale-Revised Edition...21

Space and Furnishings................................21

Personal Care Routines..............................23

Language-Reasoning...............................22

Activities..........................................23

Interaction........................................24

Program Structure...................................26

Parents and Staff..................................25

Quality of Childcare in the U.S. as measured by the ECERS.....26

West Virginia Universal Pre-k Program....................................29

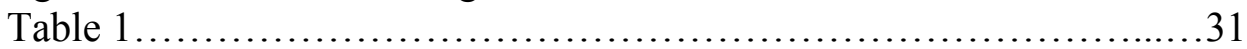

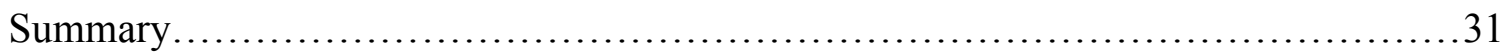

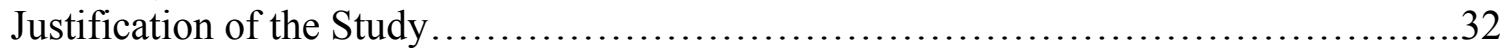

CHAPTER II

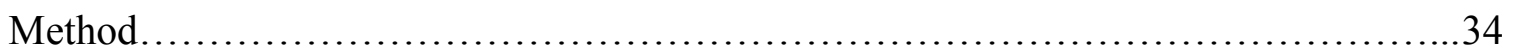

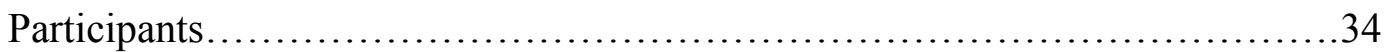

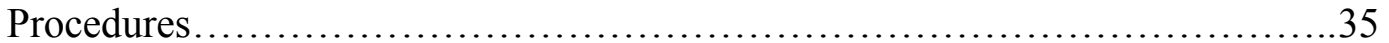

Measures.................................................................... 37

Data Analysis...................................................41

CHAPTER III

Results.... 


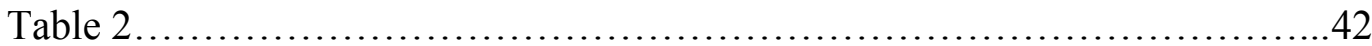

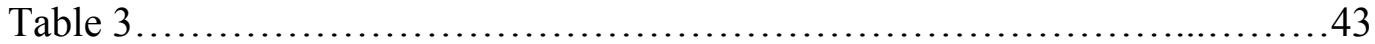

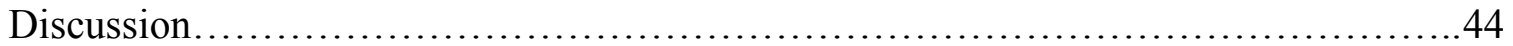

Space and Furnishings............................................... 44

Activities......................................................... 45

Program Structure...................................................46

Total Scores.............................................................48

Personal Care Routines....................................................48

Language-Reasoning................................................ 49

Interaction.......................................................... 50

Parents and Staff.................................................. 51

Summary.................................................................. 51

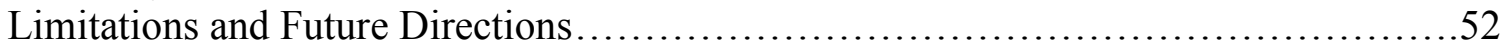

Conclusion.............................................................. 53

References................................................................... 54 


\section{Chapter I}

\section{Overview}

The benefits of quality early childhood experiences cannot be denied. There are prominent longitudinal studies that have proclaimed that investing in quality educational environments for young children results in major societal benefits. Some of the most prestigious studies include the Perry Preschool Project (Weikart, 1967), the Early Training Project (Gray \& Klaus, 1970), and the Philadelphia Project (Beller, 1972). The Perry Preschool Project has been quoted frequently with its findings that children who attended high quality programs had greater income, were more likely to graduate high school, greater chance of keeping a job, and had committed fewer crimes than children who did not receive a high quality education (Weikart, 1967). These children were assessed throughout their life and most recently at age 40. Similar results were found in the Early Training Project (Gray \& Klaus, 1970) and the Philadelphia Project (Beller, 1972). More recently, results from the Abecedarian Early Intervention Project (Campbell, Pungello, Burchinal, Kainz, Pan, Wasik, Barbarin, Sparling, \& Ramey, 2012; Campbell, Ramey, Pungello, Sparling, \& Miller, 2002; Campbell \& Ramy, 1994) and the Abbott Preschool Program (Barnett, Jung, Youn, \& Frede, 2013) continue to substantiate the earlier findings regarding the benefits of a quality early childhood experience.

Associations between Head Start and academic achievement were made recently in a study conducted by Cooke (Cooke, 2007). Intensive, high quality, ecologically pervasive early interventions can yield significant improvements in cognitive, academic, and social outcomes for at-risk children (Ramey \& Ramey, 1998). In essence, these longitudinal 
studies give support to the importance of quality in child care environments and their effect on lifelong success.

Knowing that quality child care produces positive results, it is important to look at the entities that affect that quality, such as the amount of regulations and the indicators that quantify that quality. The entire landscape of early childhood programs in the United States is changing. Thirty-nine states offer state funded early childhood programs. These programs include Head Start, pre-k programs, nursery schools, child care centers, etc. with 12 states and Washington D.C. offering universal pre-k classrooms (Morrissey, 2007). Universal pre-k expands access and availability to pre-k programs to all fouryear- olds within that state. This emphasis on early childhood has resulted in the creation of state policies which enforce the compliance of content standards for pre-k programs. State early learning standards are present in all but two states (Barnett, Carolan, Fitzgerald, \& Squire, 2011). This exemplifies that early childhood programs have the same type of educational direction as kindergarten programs. These standards put in place the goals and objectives for pre-k classrooms.

To further demonstrate the importance of early childhood, states are also requiring that teachers have more specific early childhood training and degrees in the field. The Improving Head Start for School Readiness Act of 2007 requires that as of September 30, 2013, at least $50 \%$ of Head Start lead teachers in center-based programs have a bachelor's or an advanced degree in early childhood education or related field (Head Start, 2007). Head Start teaching assistants in center-based programs must have at least a Child Development Associate (CDA) credential or be enrolled in a program leading to an associate or bachelor's degree, or registered in a CDA credential program (Head Start, 
2007). The increase in the number of preschool programs, the addition of preschool content standards, and additional staff requirements relays a message that early childhood is considered an area of significance. To top this off, President Obama in his 2013 State of the Union address reiterated the importance of early childhood education for later school success.

This current movement for stricter requirements in preschool programs to ensure quality coincides with other indicators that are occurring in early childhood programs. For example, research has found that quality centers have teachers with higher pay and more teacher education (Cryer, Tietze, Burchinal, Leal, \& Palacio, 1999). Environmental issues have also been found to play an important part in quality (Cryer, Harms, \& Riley, 2003). Environmental quality in these terms refers to the environment the child experiences in the classroom. Environmental quality has been calculated by various means such as the Observational Record of the Childcare Environment (NICHD Early Child Care Research Network, 2000), Classroom Practices Inventory (CPI; Hyson, HirshPasek, and Rescorla, 1990), Classroom Assessment Scoring System (CLASS; Pianta, La Paro, \& Hamre, 2008), and the Early Childhood Environmental Rating Scale-Revised Edition (Cryer, et al., 2003). Historically, the Early Childhood Environmental Rating Scale- Revised (ECERS-R) has been the instrument most widely used across programs to measure the environmental quality of a program.

Looking at environmental quality leads to the current study on pre-k classrooms in West Virginia. In West Virginia, pre-k classrooms for four-year-olds are located in a variety of settings. They are in public schools, licensed child care centers (both private and public), private or faith based facilities and Head Start centers. Some pre-k 
classrooms are combinations of the above programs and are called pre-k collaboratives. The West Virginia Department of Education regulates universal pre-k programs through WV Public Policy 2525 (Department of Education, 2012). This law states that at least $50 \%$ of universal pre-k programs that are under the jurisdiction of the State Department of Education must be operated in an approved community based program. This means that there are universal pre-k programs located in child care centers, Head Start centers and other community programs. These are referred to as collaboratives. The intent of these collaborative programs is to provide children with pre-k experiences in an appropriate, natural setting. Children who are already enrolled in child care will not have to adjust to a new facility for their pre-k experience. Parents who need full day child care will not have to make additional stops when picking up their children. In contrast, there are also universal pre-k classrooms located in public schools. All universal pre-k classrooms physically located in public schools must have a certified teacher in early childhood or a related field. Universal pre-k programs located in the collaborative settings, according to WV Public Policy 2525, must have teachers with a professional teaching certificate in early education, preschool education, or preschool special needs. However, when no fully certified teacher is available, a collaborative teacher must possess a bachelor's degree and meet requirements for licensure of professional/paraprofessional for permanent authorization endorsed for community programs (Department of Education, 2012).

There are pre-k programs in child care centers that serve four-year-olds who are not associated with the West Virginia universal pre-k but rather serve as a childcare classroom for children whose parents need full day childcare. Pre-k programs in child 
care centers that are not affiliated with the West Virginia Department of Education as State universal pre-k programs are classrooms with teachers that are not mandated to follow WV Public Law 2525 and teachers do not have to have a degree or certification. These are non-collaborative classrooms located in child care settings that fall under the auspices of child care and are regulated by the West Virginia Department of Health and Human Resources. Therefore, there are two different types of pre-k classrooms located in child care centers in West Virginia. There are universal pre-k classrooms operated by the State Department of Education that are housed in child care centers (collaboratives). They must follow the regulations of the State Department of Education and the West Virginia Department of Health and Human Resources. Secondly, there are pre-k classrooms in child care centers that are operated only by the regulations of the West Virginia Department of Health and Human Resources and not affiliated with the State Department of Education (non-collaboratives).

For the purposes of this study, the researcher investigated the environmental quality of universal pre-k collaborative classrooms that are regulated by the aforementioned entities and the quality of non-collaborative pre-k classrooms in child care centers which are strictly child care and regulated by one entity. This guides the direction of this study. The research question was: Are there subset differences on the Early Childhood Environmental Rating Scale-Revised Edition in pre-k collaborative classrooms and pre-k non-collaborative child care classrooms in reference to the following subscales: Space and Furnishings, Personal Care Routines, LanguageReasoning, Activities, Interaction, Program Structure, Parents and Staff? 


\section{Review of Literature}

First, an examination of Bronfenbrenner's Ecological Systems Theory is reviewed to demonstrate how the larger picture of the national educational climate influences the experiences provided to children at the more local level. In addition, indicators of quality related to pre-k and preschool programs are discussed. Generally, it is agreed that teacher education and knowledge, teacher wages, and teacher/child ratio play an important part in the overall quality of the classroom. These factors are part of the structural quality of child care. Structural and process quality encapsulates quality issues in child care. It is also essential to review the mechanisms for measuring quality. Assessments used to measure environmental quality include the Observational Record of the Childcare Environment, Classroom Practices Inventory, Classroom Assessment Scoring System, and the Early Childhood Environmental Rating Scale-Revised Edition. Lastly, West Virginia pre-k is examined pointing out the differences in the regulations for pre-k collaboratives and non-collaboratives in child care centers as this is the basis for the research question. Below is a detailed review of the aforementioned.

\section{Ecological Systems Theory}

Captivating Bronfenbrenner's theory, pre-k classrooms are influenced by the greater picture of the country's educational climate and economic conditions (Bronfenbrenner \& Morris, 1998; Cryer, et al., 1999; Brendtro, 2006). This environment helps to determine and set the priorities for early childhood education both nationally and in individual states. Bronfenbrenner's ecological model describes environments as contexts for development. The model is comprised of different systems experienced by the developing child: the microsystem, the mesosystem, the exosystem, the macrosystem, 
and the chronosystem. In the model, the microsystem is made up of the activities, social roles, and interpersonal relations experienced by the developing child in his or her immediate environment (Bronfenbrenner, 1994). The microsystem includes settings such as family, school, classrooms, and peer groups. The content and structure of the microsystem effects the operation to produce and sustain positive development, or otherwise. The macrosystem in this model also plays a significant role in the development and education of the child. This layer is comprised of the culture or subculture of the child's in-group consisting of belief systems, opportunity structures, customs, lifestyles, laws, and factors embedded within these systems (Bronfenbrenner, 1994). These societal factors include teacher regulations, teacher requirements and teacher wages, all of which are said to have an effect on the quality of the classroom. Recent federal laws such as the Improving Head Start for School Readiness Act of 2007, specifies higher teacher educational requirements. Universal pre-k classrooms in West Virginia also collaborate with Head Start, therefore raising the bar for all pre-k programs. Nationally, $50 \%$ of Head Start teachers must obtain a degree or certification by September 30, 2013 (Head Start, 2007). West Virginia with its proposed educational reform is in the midst of requiring higher standards for pre-k teachers and assistant teachers. Some counties in West Virginia take it a step further and require their pre-k teachers to obtain a dual certification in pre-k and special education. All of these systems are continually working together in a cyclical pattern stimulating the child's development, with the structural factors of the macrosystem having a direct affect on the microsystem that the child experiences. 


\section{National Trends in Early Childhood}

Early education in the United States has been a priority, with strides to encourage states to progress towards universal pre-k programs. Today there are 51 pre-k programs in 39 states plus two programs in Washington D.C. (Barnett, et al., 2011). The importance of early education is also demonstrated by current national efforts such as the Race to the Top Grants (U.S. Department of Education, 2011) which assists states in building quality improvement through the development of their Quality Rating and Improvement Systems (QRIS). Required components of the Race to the Top Grant include staff qualifications, curriculum, administration, parent and family involvement, licensing compliance, teacher-child ratios and group size. All these factors affect quality of early childhood programs. This federal grant program has influenced the direction of many states including West Virginia. West Virginia's commitment to early childhood programs and universal pre-k has resulted in the establishment of the WV Pre-K Continuous Quality Improvement Advisory Council and numerous subcommittees to focus on initiatives, pre-k improvement and other relevant issues in early childhood. This state council is influenced by national initiatives and has authority over what is happening in local early childhood arenas in West Virginia. Once again the macrosystem of the current culture trickles down to the microsystem of the classroom.

State standards for quality have improved over the past decade (Barnett, et al., 2011). Placing more extensive regulations on pre-k programs appears to be one action that increases quality. Classrooms in states with less stringent regulations have lower quality (Peisner-Feinberg, \& Burchinal, 1997). Although nationally the past decade has 
shown an increase in pre-k programs, long term data reveals that the funding to support program quality has not grown as quickly as the increase in number of programs.

\section{Structural and Process Quality}

Classroom quality is influenced by many different factors, which can typically be categorized into constructs of structural quality and process quality. Structural quality is comprised of factors such as teacher education, teacher knowledge, group size, and ratios. Process quality are the experiences the children encounter that are carried out to protect children's health and safety and to encourage their positive development physically, linguistically, intellectually, emotionally, and socially (Cryer et al., 1999). This includes interactions that occur between the teacher and the child, the accessible materials and activities, and the personal care routines that are managed by the teacher. When structural quality is regulated and there is a caring teacher, process quality can also be improved (Bordin, Marchida, \& Varnell, 2000; Cryer, 1999). In contrast, aspects of process quality can be hindered if structural quality is poor.

Aspects of structural quality. It has been well-established in research that structural quality provides a framework and is linked to process quality (Phillipsen, Burchinal, Howes, and Cryer, 1997; Cryer et al., 1999; Bordin, Marchida, \& Varnell, 2000; Barnett, 2003; Smith, 2005; Early, Bryant, Pianta, Clifford, Burchinal, Ritchie, Howes, Barbarin, 2006; Bogard, Traylor, \& Takanishi, 2008). As previously stated, these structural features refer to factors such as teacher education, teacher knowledge, group size, and ratios. This represents the macrosystem within Brofenbrenner's systems theory.

According to the Cost, Quality and Child Outcomes in Child Care Centers (1995)

study, when structural quality is strictly regulated, process quality can be improved. Child 
interaction, experience, and environment are aspects of process quality that represents the microsystem.

In a study conducted by Phillipsen and colleagues (1997), structural characteristics in child care centers were examined for associations with observed process quality of care. Results showed that in states where there were more stringent child care regulations there was higher process quality. Teacher education, teacher-child ratios, and group size are aspects of structural quality that are easily regulated by the state. It is more challenging to regulate teacher wage; however it is a factor that is strongly related to teacher education and training requirements. (Phillipsen et al., 1997; Phillips, Mekos, Scarr, McCartney, \& Abbott-Shim, 2000). The following examines different aspects of structural quality specifically in West Virginia pre-k classrooms.

Teacher education. Teacher qualifications and education are factors of quality in all classrooms. West Virginia Department of Health and Human Resources requires that lead teachers in any pre-k classrooms in a child care center "have to be at least twentyone years of age and have a minimum of one year of relevant work experience and one of the following additional qualifications: a.) A CDA (Child Development Associate) credential and three hundred hours of relevant work experience working with young children or twelve college credits in an early care and education field and three hundred hours of relevant work experience working with young children; b.) A total of two years of relevant work experience; c.) A registered Apprenticeship Certificate for Child Development Specialist, or twenty-eight college credits, with at least nine credit hours in early childhood development.” (West Virginia Department of Health HR Child Care 
Regulations, 2009 p.24). West Virginia Kids Count (2012) reported that nearly 60\% of WV child care workers had no training in caring for children.

On the other hand, pre-k collaborative classroom teachers must have a professional teaching certificate in early education, preschool education, or preschool special needs. When no fully certified teacher is available, a teacher must possess a bachelor's degree and meet requirements for licensure of professional/paraprofessional for permanent authorization endorsed for community programs (Department of Education, 2012). As of August 1, 2013, all newly hired teachers in collaborative classrooms will be required to have a minimum of a Bachelor's degree (Barnett et al., 2011).

Research has pointed out that the quality of care and the child's development is associated with teacher level of education (Burchinal, Howes, \& Kontos, 2002; ClarkeStewart, Vandell, Burchinal, O’Brien, \& McCartney, 2002; Lanigan, 2011; Raikes, Raikes, \& Wilcox, 2005). In the early childhood field, it is suggested that process quality improves with higher teacher education, a factor of structural quality, though there are numerous structural factors that affect this outcome. With higher levels of education, teachers are more likely to provide better language development, learning activities, and have better knowledge of basic care (Cryer, 1999; Norris, 2001).

A study by Early and colleagues (2006) examined structural quality, specifically teachers' education level and their relation to the quality of the classroom and the academic advances made during pre-k. Multiple observations, child assessments, and questionnaires answered by teachers were used to gather data. Researchers found that there was a relation between the teacher's level of education and children's higher math 
skills, whether the teacher's level of education is categorized by years, highest degree or Bachelor's degree. A Bachelor's degree was associated with the child having the most significant gains. Children's gains in basic skills such as rhyming, naming letters and colors were associated with teachers with a Child Development Associate's (CDA) certificate. Interestingly, teachers with education higher than a Bachelor's degree earned higher scores on the Early Childhood Environmental Rating Scale's teaching and interaction subscales than teachers who have an Associate's degree and only teachers with higher than a Bachelor's degree provided higher quality instruction. It is important to note that teacher education, training, and credentials alone do not show consistent relations with classroom quality or other academic gains for children (Early, et al., 2006); other structural features must be accounted for simultaneously to show the positive effect on process quality.

It is not a requirement of pre-k teachers in non-collaborative classrooms to obtain a bachelor's degree to teach in child care settings; however it is strongly encouraged for teachers in the child care setting to obtain or pursue a CDA degree. Teachers in West Virginia child care settings are required to be registered in West Virginia State Training and Registry System (S.T.A.R.S.; West Virginia Department of Health and Human Resources, 2009). The focus of the program is to improve the quality of care and education for early childhood education of young children and their families in West Virginia. This program guarantees that teachers will obtain their West Virginia mandated 15 hours of registered training each year under the WV S.T.A.R.S. This program provides training in early care and early core knowledge in different areas: child growth and development, child observation and assessment, curriculum, family and community, 
health, safety and nutrition, positive interactions, relationships, professionalism, and program management. Child care teachers who are registered with the WV S.T.A.R. S. have a choice in which training he/she she chooses to attend. Ideally, teachers would choose training throughout each of the domains. Due to the qualifications required for non-collaborative pre-k classrooms in child care centers, and pre-k collaborative classrooms, it can be presumed that pre-k collaboratives would have higher quality care.

Teacher wage. Teacher education, teacher-child ratios, and group size are aspects of structural quality that are easily regulated by the state. Teacher wage is less easily regulated, however it is strongly affected by teacher education and training requirements (Phillipsen et al., 1997; Phillips, et al., 2000).

Teacher wages have been shown to be one of the strongest predictors of process quality, even stronger associations than teacher-child ratios or teacher education (Scarr, Eisenberg, \& Deater-Deckard, 1994). Lead teacher wages was also a significant predictor of quality in the classroom. Teacher wage is associated with stability of care and in turn, the formation of attachment between teachers and children which shown to be related to program quality and child development (Barnas \& Cummings, 1994; Phillips et al., 2000; Whitebook, Howes, \& Phillips, 1989). More highly qualified teachers are going to be drawn to centers who can offer greater wages, and these centers can be more selective in the teachers they hire. Though teacher wage is a strong predictor of process quality, it must be recognized that teacher education and state demographics affect this factor; wage does not typically occur in isolation from other structural factors. This macrosystem factor of teacher wage is one that plays a significant role in quality. 
In West Virginia, according to Public Policy 2525, the center who has a pre-k collaborative receives enough State funding to pay the pre-k classroom teacher a salary equivalent to a teacher in the public school system (Department of Education, 2012). The salary of a teacher in a pre-k non-collaborative classroom in a child care centers is set individually by the center. WVDHHR does not employ any policy of a minimum salary for pre-k teachers. There are no regulations that mandate a pay scale be used in the noncollaborative child care classrooms.

Teacher-child ratio. According to WVDHHR, a four year old classroom must have one qualified staff member for every 12 children, with no more than 24 children in a group. Pre-k collaborative classrooms, however, can have no more than 20 children in a group mandated by the West Virginia Department of Education and there must be one qualified staff member for every 10 children (Department of Education, 2012). The significance of teacher-child ratio is varied among the research. The National Institute of Child Health and Human Development (NICHD) Early Child Care Research Network (2000) found that teacher-child ratio was one of the most reliable predictors of positive caregiving over time for children in child care for children ages 15 months of age to 36 months.

The difference in the regulations of WVDHHR child care and WV Public Policy 2525 of WV Department of Education pertains to the number of mandated staff required with group size. The teacher child ratio is better in collaborative pre-k classrooms in West Virginia.

Process Quality. Process quality is the actions that the children experience daily that are carried out to protect children's basic health and safety needs and also to 
encourage their positive physical, language, intellectual, emotional, and social development (Cryer et al., 1999). This includes interactions that occur between the teacher and the child, the accessible materials and activities, and the personal care routines that are managed by the teacher. Focusing on the importance of the quality of the interactions among teachers, teacher-child interactions, and interactions among children, and the variety of materials accessible in the classroom mirrors the widely accepted view that the effects of early education settings take root in these early experiences and connections (Howes \& Ritchie, 2002; Pianta, 2000). It is impossible to talk about process quality without discussing how it is strongly related to structural quality. The National Institute Early Education Research (NIEER) has stated that the most impressive development of the quality of pre-k is the adoption of the Early Learning Standards (Barnett, et al., 2011). These standards are in all but two states. West Virginia Policy 2525 requires that pre-k collaborative teachers use this framework of the early learning standards in their classroom lesson planning. The WVDHHR does not mandate the use of the WV Early Learning Standards in the non-collaborative pre-k classrooms.

Teacher wage has been shown to be a strong predictor of process quality; some research suggests even stronger associations than teacher-child ratios or teacher education (Scarr, et al., 1994). Teacher wage is associated with stability of care and in turn, the formation of attachment between teachers and children which are related to program quality and child development (Barnas \& Cummings, 1994; Phillips et al., 2000; Whitebook, et al., 1989). More highly qualified teachers are drawn to centers that can pay higher wages, and these centers can be more selective in the teachers they hire. As previously noted, teacher wages are a great predictors of process quality, but the 
determinants for wage (education, state demographics) are also structural factors of quality that affect process quality (Phillips et al, 2000). However, a relationship was shown between higher teacher education and better teacher-child ratios and higher scores on the ECERS-R (Cryer et al., 2003). Furthermore, center demographics such as lower center enrollment and a lower proportion of infants, toddlers and subsidized children also predicted higher process quality for preschoolers.

A study conducted by Smith (2005), investigated structural characteristics and their relation to process quality. This study included 100 child care center classrooms for 3 to 5 year old children and used the ECERS-R scale to assess quality of the pre-k programs. A provider survey was also conducted via telephone between the researcher and the childcare center director. The questions were to give the researcher background demographic information regarding the centers funding, costs, and teacher wage to give insight into the programs structural factors. Smith found that the following structural factors were strong predictors of process quality in pre-k classrooms: teacher and director pre-service education, teacher and director continuing education, teacher and director wages, provision of benefits to staff, and training budget per staff member (Smith, 2005). Higher education was found to support the knowledge and skills needed to provide abundant verbal and cognitive stimulation, being responsive to the children, and to give the young children ample amount of attention and support. Also noteworthy, continuing education experiences were related to high quality classrooms, particularly pre-service experiences. Contrary to past research, Smith found that classroom structure was not a significant predictor of process quality. 
Howes, Burchinal, Pianta, Bryant, Early, Clifford, and Barbarin (2008) investigated the relationship between academic advances and social competence over the pre-k year with regard to kindergarten readiness. The results of this study showed that children exerted greater gains in academic outcomes when higher quality instruction or positive teacher-child relationship was experienced. In contrast to past research, relations were not shown between academic or social gains and other factors of structural quality (i.e. ratio, teacher qualifications, and program location and length). The findings have implications for a range of state and local policy and program development efforts as well as for theories of contextual influences on development (Howes et al., 2008).

In a study conducted by Burchinal, Vandergrift, Pianta, and Mashburn (2010) data of 11-state pre-k classrooms investigating indicators of process quality that are related to structural quality were analyzed, particularly teacher education and teacher-child ratio. Classrooms were evaluated using the Classroom Assessment Scoring System (CLASS). The CLASS assessment evaluates two dimensions of the quality of teacher-child interactions within pre-k classrooms, instructional quality and emotional support (Burchinal et al, 2010), based on six indicators: receptive language, expressive language, math, reading, social skills, and behavior problems. The results indicate that social outcomes were more impacted by the quality of teacher-child interactions, but only when teachers are actively and positively engaged with children per indication on the CLASS Emotional Support Scale (Burchinal et al, 2010). Young children need a caregiver who actively and positively engages them in order for these teachers to be able to teach or modify social skills (Hamre \& Pianta, 2005). Further results suggest that quality of instruction is related to language, reading and math skills more strongly in higher quality 
than in lower quality classrooms. These findings imply that high-quality classrooms are necessary to improve social and academic outcomes in pre-k programs for low-income children (Burchinal et al, 2010).

Measuring Environmental Quality. Current measures assess the social environment and the learning environment at a very general level, but only a few adequately assess practices related to academic skill domains. Development of observation measures is just beginning to catch up with the increased political emphasis on academic preparation and school readiness. Early measures included only a few very general items related to practices designed to promote language and cognitive development. Thus, for example, many measures include items assessing the degree to which children choose activities, but few provide very much information on the degree to which children are given specific kinds of opportunities to develop literacy, mathematical, or science skills.

Currently, there are several measures that have been developed that are used in classroom settings to measure process quality including: Observational Record of the Childcare Environment, Classroom Practices Inventory, Classroom Assessment Scoring System, and the Early Childhood Environmental Rating Scale-Revised Edition. Widespread efforts are being placed on identifying the features of programs that can be regulated to guarantee access to quality child care (Barnett, et al., 2003).

Selected observational measures that have been developed and used to assess quality in early childhood programs are summarized below. Few measures have demonstrated effects on child outcomes, although most assess practices that have been associated with positive child outcomes. Observers using and implementing these 
measures must have thorough and adequate training in order for these assessments to be used properly and reliably. The developers of some measures require their own training and certification.

Observation Record of the Caregiving Environment. The Observation Record of the Caregiving Environment (NICHD Early Child Care Research Network, 2000) is an assessment that focuses on the sensitivity and responsiveness of the caregiver to a child. It is developed to be used in home or center based child care. The observation period occurs over one or two 3-hour visits to the home or center based child care. The observer collects observations of behaviors and completes ratings of the child's caregiver. The behavior scales provide a record of the occurrence of specific acts, and the qualitative scales take into account the quality of the caregiver's behavior in relation to the child's behavior. The most frequently used quality measure is positive caregiving and is calculated slightly differently for each age level. At six, 15, and 24 months, positive care giving scores are the mean of five 4-point qualitative ratings: sensitivity to child's nondistress signals, stimulation of cognitive development, positive regard for child, emotional detachment, and flatness of affect. However, at 36 months, two additional subscales, "fosters child's exploration" and "intrusive", are included in the composite (NICHD Early Child Care Research Network, 2000). In preschool classrooms, the positive caregiving composite is the mean of 4-point ratings of caregivers' sensitivity and responsiveness, stimulation of cognitive development, intrusiveness, and detachment (NICHD Early Child Care Research Network, 2000). The behaviors observed include language stimulation, positive talk, positive physical contact, positive affect, stimulation of social development, restricting activity, speaking negatively to child, as well as the 
amount of time the child positively or negatively interacted with the caregiver and other children (NICHD Early Child Care Research Network, 2000). The goal of the OCRE is to focus on the care giving environment the child experiences. While research has shown that high quality interactions are a major factor of process quality, this assessment does not evaluate other aspects such as activities and accessible materials.

Classroom Practices Inventory. The Classroom Practices Inventory (CPI; Hyson, et al., 1990) was developed to in order to differentiate between developmentally appropriate practices, according to 1987 guidelines of the National Association for the Education of Young Children (NAEYC), and highly instructive practices, focusing on the teaching practices the teacher uses with the entire preschool classroom. The measure is comprised of 26 items which are divided into two subscales. The emotional climate subscale assesses the teacher's warmth, encouragement, and positive guidance. In the program focus subscale, half of the 20 items refer to instructive, teacher-directed practices including large-group instruction, workbooks, ditto sheets, flashcards, memorization and drill, art projects that involve copying, focus on getting the right answer, methods which were considered developmentally inappropriate by NAEYC. Of the remaining ten items that describe positive activities, most concern child choice, initiative, and diversity of activities and materials that children can manipulate. Three of the items refer to positive instructional approaches such as, "teachers ask questions that encourage children to give more than one right answer". The CPI assessment gives a thorough evaluation of aspects of process quality; however some aspects are not included such as furnishings, safety practices, and parent and staff involvement (Hyson, et al., 1990). 
Classroom Assessment Scoring System. The Classroom Assessment Scoring System is a common measure that is comprised of three domains consisting ten dimensions (Pianta, et al., 2008). The first domain "Emotional Support" contains the dimensions: positive climate, negative climate, teacher sensitivity, and regard for student perspective. The next domain, "Classroom Organization," includes behavior management, productivity, and instructional learning formats. Lastly, "Instructional Support" is comprised of concept development, quality of feedback, and language modeling. Scoring is completed after four to six rounds of observation for twenty minutes followed by a ten minute scoring section. Each dimension is averaged out to calculate the domain scores. This assessment does not result with one overall score but rather three scored sections. Accuracy in using this scale requires a well-trained observer who invests time in using the tool well (Pianta et al., 2008). The CLASS gives a broader sense of the classrooms' process quality in that it addresses many different aspects of process and environmental quality. However, the scale is not in-depth and greater detail may be needed for an accurate representation of the process and environmental quality of a program.

Early Childhood Environmental Rating Scale-Revised Edition. The Early Childhood Environmental Rating Scale-Revised Edition (ECERS-R), containing indicators for 43 items across seven subscales, is also used to assess environmental quality throughout the country (Cryer, et al., 2003). The following descriptions of the subscales express the importance of these process quality factors.

Space and Furnishings. The physical layout of a pre-k classroom should be large enough that children are not crowded and toys and materials can be neatly organized as 
well as in good condition. The furniture should be of appropriate size to support children's independence, safety, and there should be a sufficient quantity for the amount of children enrolled. The classroom should be furnished with soft toys and materials that are accessible to the children for a substantial portion of the day. Room arrangement should allow for adequate supervision. There should be separate interest centers with well organized toys and materials to allow or a variety of learning and play opportunities. The space for gross motor should be adequate for all children enrolled in the program and the equipment much be safe and of appropriate size. Following these recommendations allows for the children to be independent, and it gives them the opportunity to be engaged in their play for extended periods of time. This extended play enhances the children's social skills, specifically peer interactions, child-teacher interactions, sharing, participating, and cooperating (Cryer et al., 2003).

Personal Care Routines. The Personal Care Routines subscale is comprised of many vital items related directly to the child's health and safety including greeting/departing, meals/snacks, nap/rest, toileting procedures, and overall health and safety practices (Cryer et al., 2003). Indicators under these items include pleasant conversation between parents and staff about the child, properly sanitized tables before serving meals, and balanced meals. It is recommended that during this time family style meals are served, with child-sized serving utensils for self help, and that the teachers sit with the children and engage in pleasant conversation and talk to the children about healthy choices (Cryer et al., 2003). Proper hand washing techniques are very strict and fall under three items in this subscale. Safety practices and health practices are very important issues that must be taken very seriously. 
Language-Reasoning. In order for a classroom to have high process quality, there must be many opportunities for children to develop and enhance their language and reasoning skills. According to Cryer and colleagues (2003), it is recommended that staff read to children daily both formally and informally. A wide selection of books must also be accessible in a variety of topics. Props such as flannel boards and puppets should also be accessible in a quiet reading area. Communication activities are to occur during free play and group times, and various materials that encourage communication should be accessible. Staff should ask questions and offer comments that encourage child talk and expands the vocabulary of the child. Written dictation of child's explanation of drawings and other activities should occur. Staff are to assist children in developing their reasoning skills by helping them to recognize concepts through materials and language. There should be a great deal of child-staff individual conversation and encouraging of children to communicate longer and more complex answers. These activities and actions support the development of the children's language, intellectual, emotional, and social skills (Cryer et al., 2003).

Activities. As mentioned previously, classrooms should have many different, well organized interest centers with adequate space for play that are accessible for a substantial portion of the day. These can include but are not limited to fine motor activities, art, music/movement, blocks, dramatic play, nature/science, and math/number activities (Cryer et al., 2003). These materials should be rotated regularly to maintain interest. Sand and water play should be accessible at least one hour daily both indoor and outdoor, weather permitting, with various toys available. There should be limited T.V. and computer use, if it is chosen to be used in the classroom. If this media is to be used, it 
should be developmentally appropriate and should encourage child and staff active participation. There should be other choice activities that the child can participate in during media use time. The use of media should extend and support the classroom learning. These interest areas offer children many new learning experiences and planned activities can be arranged around each interest area (Dodge, Colker, \& Heroman, 2002). Promoting acceptance of diversity is an item under the Activities subscale as this should be evident through all interest centers and activities in the classroom through a variety of materials. Classrooms should have materials that show racial and ethnic diversity, people with differing abilities, and people in non-stereotyping roles throughout the room including dolls, dress-up clothing, pretend food, books, pictures, musical instruments, art materials from other cultures, and other areas that show diversity in a positive way. Staff must also intervene to counteract prejudice in the classroom.

Interaction. This subscale focuses on child/staff interaction during supervision of children, discipline, child-staff interactions generally, and also interaction among children (Cryer et al., 2003). With regard to child-staff interaction, they should be positive, pleasant, helpful, and encouraging. Staff should maintain control of the classroom in a positive way, with a few fair and consistent rules. Interaction that occurs should however, be more conversation and pleasant and less on controlling the classroom. Staff should add information to extend children's thinking and ask open ended questions to encourage children to explain and think. There should be non-punitive and effective discipline with staff redirecting inappropriate behaviors. Staff should also actively involve children in solving their own problems and conflicts and also provide activities to help children understand social skills such as group discussions, reading books about common conflicts 
and problems, or using puppets or role lay to act out common conflicts and problems and using different ways to solve them. Peer interaction should be positive and appropriate and should be modeled by staff. Staff should encourage cooperation among peers and should help shy children to find peers to interact with.

Program Structure. This subscale relates to what the children actually experience daily. The schedule should be posted and should be appropriate for children. The schedule should not be too rigid, however, for the times when flexibility is needed. The schedule should offer a variety of experiences indoor and outdoor, active and less active, and teacher-directed and child-initiated activities. Transitions should be smooth and should not require long waiting periods for the children. There must be opportunity for free play for a substantial portion of the day, which is a time when children can independently choose activities and peers to play with. Large or whole group activities are beneficial as the children gain experience cooperating and conforming to meet the needs of the whole group, and utilizing self-control, however, these whole group times should be limited throughout the day as most children receive little personal interaction. If there is a child with disabilities in the classroom there must be modifications made in the environment, program, and schedule to meet the needs of the child with a disability so they may participate inclusively with their peers (Cryer et al., 2003). There should be enough staff available so the child will have adequate assistance. Professional intervention should mostly occur within the classroom setting. Both parents and classroom staff should have significant knowledge of the child's progress as well as ideas for activities that will help encourage the child's progress. 
Parents and Staff. There should be positive interactions between parents and staff, with sharing of child-related information and possibilities to be involved in the children's program (Cryer et al., 2003). Parents should also have an opportunity to complete annual evaluations of the programs to be sure that parents are able to express their opinions. Parents should also serve on the advisory board or be involved in decision making roles. Provisions for personal needs of staff should include access separate space away from the children, adult sized furniture, adult restroom, adult lounge area, and staff breaks daily. With regard to professional needs of staff, they should have access to a telephone, file and storage space, space for individual conferences, and space for adult group meetings (Cryer et al., 2003). There should be positive and pleasant communication and cooperation between staff. Staff working together in the classroom should be able to meet for planning time at least once every other week. The responsibilities of the staff members should be clearly defined to help the classroom routines run smoothly. There should be annual observations and evaluations of staff that identify strengths of the staff members as well as areas of improvement (Cryer et al., 2003). Feedback should be helpful and supportive and recommendations for improvement should be implemented. Opportunities for professional growth of the staff should be a regular occurrence through monthly staff meetings, and staff on-site access to professional resource materials that are current. Staff should have the support to be able to participate in courses, conferences, workshops, or formal education in order to grow professionally.

Quality of Child Care as measured by ECERS-R in the United States. It is recognized that classrooms have both strengths and weaknesses when measured by the ECERS and ECERS-R. A pattern of similar issues is occurring in classrooms across the 
United States. Cryer (1999) specifies quality of care provided in most centers in the United States as mediocre, meaning only basic health and safety are met with minimal warmth and learning experiences provided by adults. She also has found that there are items and indicators that consistently have negative effects on the quality of child care. Typically, the lowest scores are in adult personal area, meals/snacks, personal grooming, child display, furnishings for relaxation, opportunities for professional growth, art, dramatic play, space to be alone, and cultural awareness (Cryer \& Phillipsen, 1997). Appreciating diversity in the classroom is a part of growing diverse culture and therefore is important for the classroom (Derman-Sparks \& the A.B.C. Task Force, 1989). According to Cryer (1999), "Space to be alone" and "furnishings for relaxation" are associated with creating and providing an atmosphere that is cozy, welcoming, and homelike.

Cryer and Phillipsen (1997) discuss classroom issues with these items; there is typically an inadequate number of soft furnishings accessible in the classroom and generally, there is no specific place set aside for privacy where the child would be protected from interruption, though a child-created space for privacy was allowed by staff. Another noted weakness was child expression of creativity through play activities. Often art materials were limited and children were often shown a model of an art project to copy for their own, rather than create their own artwork based on their own experiences. The children's individualized artwork was not often displayed which hinders the quality rating as well. Dramatic play was often found to be lacking in themes, providing only "housekeeping" as opposed to a variety of themes that would allow children to have new experiences, thoughts, and creative, mature play in different 
scenarios. Although adequate meals were served, the meals/snacks item has been shown to have lower scores in pre-k classrooms. This is greatly due to mealtimes not encouraging self-help or social skills. It has also been shown that health practices (specifically personal grooming) also receive low scores mostly due to lack of adequate hand washing. Hand washing is a practice that must be consistent and occur before eating, after toileting, or in other instances when hands may be soiled as a preventative measure against the spread of illness and germs. With regard to staff provision, it is usually found that there are often not adequate spaces for adults' personal needs, as well as lack of resources to give staff the opportunity to for professional growth. West Virginia ranks 31 among states in the overall quality of centers (National Association of Child Care Resource \& Referral Agencies, 2010).

Warash, Markstrom, and Lucci (2006) conducted a study which investigated factors that lead to quality child care centers. The ECERS-R was used as an effective training device to instruct directors and classroom teachers in child care centers what constitutes a quality classroom. The researchers conducted a pre-test on the participating classrooms, used the specific scores to train the directors on how to improve on each of the 43 items in the ECERS-R. The classrooms were then evaluated in a post-test. Results of this study showed that the ECERS-R can be used as a tool to improve the quality of child care centers (Warash et al., 2006). This further validates using the ECERS-R in the current study to measure quality of pre-k collaborative classrooms in child care centers.

The ECERS-R is widely used in child development research and is considered a good comprehensive assessment of the overall day-to-day quality of care provided for children (Phillipsen et al., 1997). There are trends in quality of pre-k classrooms 
throughout the country, with commonalities in consistent low scoring and high scoring subscales. In this study by Warash and colleagues (2006), it was found that training teachers on the ECERS-R significantly improves the quality of the classroom environment.

\section{West Virginia Universal Pre-k Classrooms}

Public Policy 2525 has been implemented in West Virginia. This policy enacts universal pre-k throughout West Virginia, providing the opportunities for parents and children to participate in pre-k services in an appropriate and natural setting. Under this policy, $50 \%$ of the public pre-k classrooms must be located in community programs (West Virginia Department of Education, 2012). During the time of the current study in $2009-10,61 \%$ of the state-funded universal pre-k classrooms in West Virginia were in collaboration with community partners. These numbers have increased for the 2012-2013 school year with $72 \%$ being in collaboration with community partners (West Virginia Department of Education, 2012). These collaborative programs are to be inclusive so all children have access to high quality pre-k. Regulations are in place to monitor the quality of the pre-k programs. Non-collaborative pre-k classrooms in child care facilities only follow regulations put in place by the West Virginia Department of Health and Human Resources (WVDHHR). Public universal pre-k classrooms in child care centers must follow the WV Department of Education regulations (West Virginia Department of Education, 2012) and WVDHHR licensing regulations. Universal pre-k collaborative classroom teachers in West Virginia must also adhere to the WV Early Learning Standards Framework and conduct the performance-based assessment on preschool children. These teachers must become reliable on the required scale which requires the 
teacher to have several, individualized, written observations for each child in various curriculum areas. In order to gain quality observations and effectively assess the child, staff must provide children with materials and opportunities to engage in high-quality play and activities. The structural quality factors regulated by WVDHHR and WV Department of Education are put in place to enhance the process quality of pre-k classrooms. To recap the emphasis of this study Table 1 on the following page reiterates the differences in regulations associated with pre-k collaborative and non-collaborative classrooms. These differences are substantial as it relates to the literature on quality factors. 
Table 1

Noted Differences in Regulations for Collaborative and Non-collaborative classrooms

\begin{tabular}{|c|c|c|}
\hline Regulation & $\begin{array}{l}\text { Department of Education } \\
\text { Regulation- Collaboratives }\end{array}$ & $\begin{array}{l}\text { WV DHHR Regulation } \\
\text { Non-collaboratives }\end{array}$ \\
\hline $\begin{array}{l}\text { Teacher } \\
\text { Wage }\end{array}$ & $\begin{array}{l}\text { Teacher wage follows the salary } \\
\text { pay scale according to WV Policy } \\
5202 \text { (Department of Education, } \\
\text { 2012) }\end{array}$ & $\begin{array}{l}\text { No state salary scale-Individual } \\
\text { centers develop their own scale }\end{array}$ \\
\hline $\begin{array}{l}\text { Teacher } \\
\text { Education }\end{array}$ & $\begin{array}{l}\text { Must have a Bachelor's degree } \\
\text { with permanent authorization or; } \\
\text { Apprenticeship for Child } \\
\text { Development Associate's Degree } \\
\text { (Department of Education, 2012) }\end{array}$ & $\begin{array}{l}\text { Required to register with the WV } \\
\text { S.T.A.R.S. and complete } 15 \text { hours } \\
\text { of continued education through this } \\
\text { system each year (West Virginia } \\
\text { Department of Health and Human } \\
\text { Resources, 2009) }\end{array}$ \\
\hline $\begin{array}{l}\text { Teacher- } \\
\text { child ratio }\end{array}$ & $\begin{array}{l}\text { One qualified staff member for } \\
\text { every } 10 \text { children; } 1: 10 . \text { No more } \\
\text { than } 20 \text { children per group } \\
\text { (Department of Education, 2012) }\end{array}$ & $\begin{array}{l}\text { One qualified staff member for } \\
\text { every } 12 \text { children; } 1: 12 . \text { No more } \\
\text { than } 24 \text { children per group (West } \\
\text { Virginia Department of Health and } \\
\text { Human Resources, 2009) }\end{array}$ \\
\hline $\begin{array}{l}\text { Child } \\
\text { Assessments }\end{array}$ & $\begin{array}{l}\text { Teachers must become reliable } \\
\text { and complete the Early Learning } \\
\text { Scale as a child assessment tool } \\
\text { (Department of Education, 2012) }\end{array}$ & No required child assessment \\
\hline $\begin{array}{l}\text { Classroom } \\
\text { Assessments }\end{array}$ & $\begin{array}{l}\text { ECERS-R observation completed } \\
\text { every } 3 \text { years and annual } \\
\text { reviews(Department of Education, } \\
\text { 2012) }\end{array}$ & $\begin{array}{l}\text { Regulatory inspection completed by } \\
\text { licensing agent conducted every } 2 \\
\text { years. }\end{array}$ \\
\hline Lesson Plans & $\begin{array}{l}\text { Use the West Virginia Content } \\
\text { Standards in lesson planning. } \\
\text { Reviewed by the classrooms' } \\
\text { respective counties' Department of } \\
\text { Education (Department of } \\
\text { Education, 2012) }\end{array}$ & $\begin{array}{l}\text { If reviewed, lessons are reviewed } \\
\text { internally }\end{array}$ \\
\hline
\end{tabular}

\section{Summary}

There is interdependency among the factors that influence quality in childcare that stems from the application of Bronfenbrenner's Ecological Systems Theory. National trends filter to state regulations and this in turn eventually affects the child. Process quality can be improved when structural quality is regulated (Bordin, Machida, \& 
Varnell, 2000; Cryer, 1999). The addition of pre-k content standards has improved the quality of classrooms (Barnett et al., 2011). On the contrary, aspects of process quality can be hindered if structural quality is poor. Structural quality includes factors such as teacher education level, teacher wage, and teacher-child ratio. This in turn relates to the research question in this study. Universal pre-k collaborative classrooms are regulated by two state agencies; the WV Department of Education requires a higher level of teacher education than WVDHHR. Pre-k classrooms in child care are regulated by one state agency, WVDHHR. Research has found that teachers with higher education and more training, specifically in a child development field, provide higher quality care. These teachers are more likely to provide better language development, learning activities, and have better knowledge of basic care (Cryer, 1999; Norris, 2001). Clarke-Stewart and colleagues (2002) also found that a child's cognitive and language development improved with higher levels of provider training and education. Higher quality is present when the provider engages children in opportunities for learning instead of the everyday routines of childcare. Pre-k collaborative teachers must meet higher educational requirements, better ratios, and have opportunities for higher wage than their counterparts in child care centers. These higher requirements would seem to produce a higher quality classroom.

\section{Justification for Study}

There are over 15,000 children (West Virginia Department of Education, 2012) enrolled in West Virginia Universal pre-k programs. Seventy two percent of these classrooms are collaboratives and are physically located in non-public school buildings (West Virginia Department of Education, 2012). This is more than the mandate of $50 \%$ of 
the collaborative classrooms must be located in community based programs. These collaborative pre-k classrooms in child care facilities follow the regulations of two State entities which would give the assumption that these programs would be of higher quality than the pre-k classrooms that are non-collaboratives. The collaborative classrooms have higher educational standards that teachers must meet. These classrooms must meet teacher-child ratios required by WV Department of Education, and are also reviewed using the ECERS-R every three years. In between ECERS-R observations, they are reviewed using other self-reporting measures. Therefore, it would be expected that these classrooms would be equipped to deliver better services as far as furnishing the classroom, following mandated personal care routines, facilitating more language opportunities, better quality activities, free play, and better interactions. There would also be an expectation of more professional growth. The Early Childhood Environmental Rating Scale-Revised is vastly used to measure environmental quality which includes components of structural and process quality.

This gives way to the purpose of this study. Are collaborative universal pre-k classrooms in child care centers of better quality than the pre-k non-collaborative classrooms in child care centers as measured by the Early Childhood Environmental Rating Scale Revised (ECERS-R)? Using the existing data from the grant entitled, "Quality Rating and Improvement for West Virginia Child Care" (Warash, 2011) the researcher looked at the ECERS-R subscale scores. This data has not been investigated as it is probably one that could be controversial depending if the outcomes show that noncollaborative programs have higher quality based on this rating scale. 


\section{Chapter II}

\section{Method}

West Virginia Department of Health and Human Resources (WVDHHR) provided funding for a 2010 grant entitled, "Quality Rating and Improvement for West Virginia Child Care." The purpose of this grant was to assess child care quality of various forms in West Virginia. The current study drew from this existing data on child care classrooms, which included collaborative and non-collaborative pre-k classrooms assessed using the Early Childhood Environmental Rating Scale-Revised (ECERS-R).

\section{Participants}

The researcher extracted the data from the Quality Rating and Improvement for West Virginia Child Care grant. In the current study there were 172 classrooms from the total 175 assessed with the ECERS-R in 39 of the 55 counties in West Virginia. The data from three classrooms had to be eliminated due to inability to label the observed classroom as either pre-k collaborative or non-collaborative. The first center had a management change since the time of the observation and was unsure as to whether or not the classroom was a collaborative. The second center did not recognize the name of the teacher that was provided on the electronic write-up of data set and the observer score sheet and was unable to give a definitive answer as to whether or not the observed classroom was a pre-k collaborative. The third center did not respond to the researchers numerous attempts to contact the facility to determine if the classroom was indeed a pre-k collaborative. Thirty-six of the classrooms were pre-k collaboratives in child care centers. This is out of the total $135 \mathrm{WV}$ collaborative classrooms in child care centers at the time data was collected. There were 136 non-collaborative pre-k classrooms in child care 
centers in this study. The total number of WV non-collaborative classrooms in child care is difficult to calculate even with personal contact from DHHR. With that said, one WV licensing specialist, stated that Kanawha County has over 30 non-collaborative classrooms (personal communication, April 11, 2013). The WV Early Care Specialist with WVDHHR, Missy Smith stated that there are 472 child care centers in West Virginia, including Head Start as of 2013 (personal communication, April 15, 2013). Of the 472 child care centers, 131 of those centers have at least one collaborative classroom in their center which means they are affiliated with the West Virginia Department of Education and WVDHHR. There are 341 child care centers in West Virginia that are not affiliated with the Department of Education and all pre-k classrooms in these centers are non-collaborative. Each of these centers have at least one pre-k classroom, with many centers having more than one pre-k classroom. In 2013, the WV Early Care Specialist stated, there are at least twice as many of non-collaborative classrooms as there are collaborative classrooms. In fact her estimation is that there was even a higher number that the number at the time of the study, as Public Policy 2525 did not mandate that $50 \%$ of universal pre-k classrooms be available to all four-year olds until 2013 (personal communication, April 15, 2013). It is challenging to determine if the sample is an exact representation of the breakdown of classrooms throughout the state of West Virginia. However, given this data from WVDHHR it becomes evident that the data sample could be interpreted as a good representation of child care in West Virginia.

\section{Procedures}

The grant recipient randomized a sample of all types of child care, assessed each randomly selected center, home, or facility, collected and entered data, collected 
demographic and contact information on the sites, and analyzed the quality of each type of child care setting, both separately and combined, based on teacher and director credentials. After obtaining consent from the Institutional Review Board, the project manager and five observer/trainers obtained two weeks of intense training on the environmental rating scales. Each was trained to be reliable on two rating scales and upon return trained each other on remaining scales. Eight more observers were trained by the project manager and observer/trainers to be reliable on two out of the four environmental rating scales.

A full list of centers, homes, and facilities was provided by WVDHHR, and a statistician created a list of randomly selected centers to assess. All centers in the state were notified by WVDHHR that they might be selected for rating through the grant. Observers were to contact centers before the visit to schedule a time to complete the assessment (Warash, 2011).

An electronic copy of the final data set of the grant on Microsoft Excel was obtained by the researcher. The results were narrowed down by using the filter option under the column "environmental rating scale" in order to view those classrooms which were evaluated using the ECERS-R.

In order to determine which classrooms were pre-k collaborative and which were non-collaborative classrooms, the researcher used the West Virginia Department of Education website, "Find my WV pre-k" (http://wvde.state.wv.us/oel/mapweb/index.php), which provides the locales of each pre-k collaborative program in West Virginia, organized first by county, then by city. The names of the pre-k collaborative programs gathered from the site were cross-referenced with the filtered results from the 
grant. The centers that were labeled as having a pre-k collaborative classroom in their facility were further verified by a phone call by the researcher to verify that the observed classroom was a pre-k collaborative classroom at the time of the observation. Three centers were not verified as to whether or not they were pre-k collaborative at the time of the observation. These three centers were eliminated from the study.

A total of 36 collaborative programs' and 136 non-collaborative programs' ECERS-R scores were analyzed and compared based on the means of their subscale scores. The data collected was hand recorded on the standard ECERS-R score sheet and then was entered in Microsoft Excel. The database, which contained ECERS-R indicator scores, from the original grant was in Microsoft Excel and imported into SPSS. Mean scores of the subscales were computed and collaborative and non-collaborative classroom scores were compared for significant differences.

\section{Measures}

The ECERS-R is a reliable and valid measure to assess quality in family child care homes. It represents an accurate portrayal of strengths and weaknesses in a program, indicating where improvements can be made (Cryer, et al., 2003). This revised version is a reliable assessment that is internally consistent and stable. Results across studies using the ECERS-R, give indication that the assessment of the global quality of an early childhood care and education setting as measured by the ECERS-R is stable over long periods of time during a given school year when the teacher is stable in the classroom (Harms, Clifford, \& Cryer, 2005). Field testing of the ECERS-R suggests that the scale demonstrates good interrater reliability at the indicator, item, and total scale levels (Harms, et al., 2005). The percentage of agreement across all 470 indicators was $86.1 \%$, 
with all indicators having a percentage of agreement over 70\% (Harms, et al., 2005). At the item level, the percentage of exact agreement was $48 \%$, with a percentage of agreement within one point of $71 \%$. Finally, for the total score, the Pearson product moment correlation was .921 and the Spearman rank order correlation was .865. The interclass correlation for the total score was .915 (Harms, et al., 2005).

The internal consistency of the Environment Rating Scales is generally assessed at the subscale and total scale level. Each of the subscales is intended to measure an aspect of quality, while the overall score is a measure of total environmental quality. The subscale internal consistency scores for the ECERS-R range from .71 to .88 , while the total scale internal consistency is .92 , according to field tests of the instrument (Harms, et al., 2005). Additionally, there is support for using the scores of the subscales and of the overall total score to represent meaningful aspects of environmental quality (Harms, et al., 2005)

The seven subscales of the ECERS are Space and Furnishings, Personal Care Routines, Language-Reasoning, Activities, Interaction, Program Structure, and Parents and Staff (Cryer et al., 2003). There are 43 items across these subscales that can be scored between one and seven. Items scored one are inadequate, three are minimal, five are good, and seven are excellent (Cryer et al., 2003). Each item's score is added together and divided by the number of items within that subscale to find a mean score that represents the quality of the pre-k program (Cryer, 1999). The key to the assessment is a well-trained, reliable observer to collect the data (Cryer et al., 2003).

Indoor space used for child care is the first item to score on the subscale under Space and Furnishings. It is desirable for all items in column one to be marked as, "No" 
and the following items, "Yes." Indicators under the first column include not insufficient space for children, toys, and furniture, space is not adequately lit, ventilated, heated or cooled, there are inadequate sound-absorbing materials, space is in poor repair to the point where health and safety are compromised, and the space is poorly maintained where health is affected. All of these items should be marked "No." The next column describes sufficient space for children, toys, and furniture, adequate lighting, ventilation, heating and cooling, and absorbing materials (Cryer et al., 2003). Space is in good repair and reasonably clean and maintained. Items in the next column include ample indoor space, good ventilation, and the space is handicapped-accessible. The last column depicts natural light that can be controlled, and controlled ventilation. Items scoring a seven would have natural light, ventilation control, easy to clean floors, walls, and surfaces, and spaces that are accessible to children and adults with disabilities (Cryer et al., 2003). All indicators for the given column, one, three, five, or seven must be met to achieve that score. If only half of the indicators are met the item is scored as the next lowest number. All indicators in the first column must be scored "Yes" to receive the lowest score of one. This is also the only column in which "No" is the desired answer. A score of two is achieved when all items under number one are scored "No" and half or more of the indicators under three are scored "Yes". A score of three is achieved when all items in column one are scored "No" and all items in column three are scored "Yes". A score of four is met when half or more of the indicators for five are met and all are met for column three. When all indicators for one are "No", and all indicators for three and five are "Yes", a score of five is given. A score of six is given when all item one indicators are "No", item three and five indicators are all "Yes", and at least half of the indicators under 
seven are marked as "Yes". A perfect score of seven is met when all items under column one are "No" and the rest of the indicators are "Yes" (Cryer et al., 2003). The remainder of items to score for Space and Furnishings include furniture for care, play, and learning, furnishings for relaxation and comfort, room arrangement for play, space for privacy, child-related display, space for gross motor play, and gross motor equipment (Cryer et al., 2003).

The next subscale is Personal Care Routines with items for greeting/departing, meals/snacks, nap/rest, toileting/diapering, health practices, and safety practices (Cryer et al., 2003). The Language-Reasoning subscale includes items for books and pictures, encouraging children to communicate, using language to develop reasoning skills, and informal use of language (Cryer et al., 2003). The Activities subscale includes fine motor, art, music and movement, blocks, sand/water, dramatic play, nature/science, math/number, nature/science, use of TV, video, and/or computer, and promoting acceptance of diversity (Cryer et al., 2003). Items under the Interaction subscale include supervision of gross motor activities, general supervision of children (other than gross motor), discipline, staff-child interactions, and interactions among children (Cryer et al., 2003). Program Structure, the next of the subscales, includes items for schedule, free play, group time, and provisions for children with disabilities (Cryer et al., 2003). The last subscale, Parents and Staff, includes the following items: provisions for parents, provisions for personal needs of staff, provisions for professional needs of staff, staff interaction and cooperation, supervision and evaluation of staff, opportunities for professional growth, (Cryer, et al., 2003). 


\section{Data Analyses}

The database from the original grant was in Microsoft Excel and imported into SPSS. Data that was entered contained scores of indicators on the ECERS-R. The indicators were grouped into respective subscales and the data was then computed by using an independent t-test to compare the means of each of the subscales in pre-k collaborative programs and non-collaborative programs. Outputs of the computations included the significance in the mean differences in ECERS-R subscales between pre-k collaborative and non-collaborative programs. The mean scores were used to assess the research question: Are there subset differences on the ECERS-R between pre-k collaborative classrooms and pre-k classrooms that are strictly child care in reference to the following subscales: Space and Furnishings, Personal Care Routines, Language Reasoning, Activities, Interaction, Program Structure, Parents and Staff? 


\section{Chapter III}

\section{Results}

The focus of the study was to determine to what extent ECERS-R subscale scores vary between pre-k collaborative and non collaborative pre-k programs that are strictly child care in reference to the following indicators: Space and Furnishings, Personal Care Routines, Language-Reasoning, Activities, Interaction, Program Structure, and Parents and Staff. Table 2 presents subscale scores and mean difference levels of subscales with significant findings for each type of program using an independent t-test. Table 3 presents the findings for each of the subscales.

Table 2

Quality Subscale Scores of Pre-k Collaborative and Non-Collaborative Programs in West Virginia as Measured by the ECERS-R that show significant findings (with Standard Deviations in Parentheses)

\begin{tabular}{lllll}
\hline Subscale & Collaborative & Non-Collaborative & $t$ & Cohen's $d$ \\
& $(n=36)$ & $(n=136)$ & $(d f=170)$ & \\
\hline Space and Furnishings & $4.58(.94)$ & $3.76(1.10)$ & $-4.14^{* *}$ & .75 \\
Activities & $4.59(1.07)$ & $3.64(1.09)$ & $-4.66^{* *}$ & .87 \\
Program Structure & $4.49(1.21)$ & $3.89(1.34)$ & $-2.42^{*}$ & .45 \\
Total Scores & $4.59(.85)$ & $4.12(.89)$ & $-2.83^{*}$ & .53 \\
\hline
\end{tabular}

Note. $* *$ Mean difference is significant at the 0.01 level * Mean difference is significant at the 0.05 level

There is a significant difference between the mean scores for collaborative and non-collaborative classrooms at the .01 level, $\mathrm{t}(170)=-4.14, \mathrm{p}<.01$. There is a significant difference between both types of classrooms within the Activities subscale at the .01 
level, $\mathrm{t}(170)=-4.66, \mathrm{p}<.01$. There is a significant difference at the .05 level between the two types of classrooms on the Program Structure subscale, $t(170)=-2.42, \mathrm{p}<.05$. Additionally, the overall ECERS-R scores of pre-k collaborative and noncollaborative programs were compared. There was a significant difference between collaborative and non-collaborative programs overall scores, $\mathrm{t}(170)=-2.83, \mathrm{p}<.05$. Table 3

Quality Subscale Scores of Pre-k Collaborative and Non-Collaborative Programs in West Virginia as Measured by the ECERS-R (with Standard Deviations in Parentheses)

\begin{tabular}{lllll}
\hline Subscale & Collaborative & Non-Collaborative & $t$ & Cohen's $d$ \\
& $(n=36)$ & $(n=136)$ & $(d f=170)$ & \\
\hline Space and Furnishings & $4.58(.94)$ & $3.76(1.10)$ & $-4.14^{* *}$ & .75 \\
Personal Care Routines & $2.70(.87)$ & $2.80(1.09)$ & .47 & .09 \\
Language-Reasoning & $5.13(1.16)$ & $4.75(1.41)$ & -1.48 & .27 \\
Activities & $4.59(1.07)$ & $3.64(1.09)$ & $-4.66^{* *}$ & .87 \\
Interaction & $5.34(1.52)$ & $5.06(1.58)$ & -.95 & .18 \\
Program Structure & $4.49(1.21)$ & $3.89(1.34)$ & $-2.42^{*}$ & .45 \\
Parents and Staff & $5.32(1.21)$ & $4.97(1.06)$ & -1.71 & .29 \\
Total Scores & $4.59(.85)$ & $4.12(.89)$ & $-2.83^{*}$ & .53 \\
\hline
\end{tabular}

Note. ${ }^{* *}$ Mean difference is significant at the 0.01 level

*Mean difference is significant at the 0.05 level

There were no significant findings for the remaining subscales: Personal Care Routines, Language-Reasoning, Interaction, and Parents and Staff. It is noteworthy to mention however, that the mean scores of collaborative classrooms were high in all remaining subscales with the exception of Personal Care Routines where only a minimal difference was shown. 


\section{Discussion}

The research question that extrapolated these findings was: Are there subscale differences (Space and Furnishings, Personal Care Routines, Language-Reasoning, Activities, Interaction, Program Structure, and Parents and Staff) between collaborative and non-collaborative pre-k classrooms on the ECERS-R? It was found that there were significant differences in Space and Furnishing, Activities, Program Structure and the total ECERS-R score.

\section{Space and Furnishings}

There was a significant difference between the mean scores of collaborative and non-collaborative classrooms for the subscale, Space and Furnishings. Higher educational requirements could be a factor in this significance finding. Collaborative pre-k classrooms scored significantly higher on this subscale than non-collaborative programs. Teachers in pre-k collaborative classrooms in child care are required to meet higher educational and training standards than the teacher of a non-collaborative classroom. This regulation is a result of WV Public Policy 2525. Again, if a pre-k teacher in a collaborative classroom does not have a certification, the teacher must have a bachelor's degree and meet the requirements for permanent authorization. Permanent authorization is a compilation of six specified early childhood courses. On the other hand, teachers in the non-collaborative classroom in child care centers do not have to meet these additional requirements. From the perspective of Bronfenbrenner's Ecological Systems theory, the macrosystem has an impact because the designated law pertaining to the higher educational requirements for pre-k collaborative teachers. In turn, these teachers should have a better understanding of setting up the environment. Teacher qualification and 
education were also related to higher ECERS-R scores in the study by Scarr and colleagues (1994).

In addition, teachers in the pre-k collaborative classroom are familiar with the ECERS-R as it a required environmental observation by a trained and reliable scorer. Having greater exposure to this tool that measures quality affords teachers to become familiar with quality room arrangement with adequate accessible materials. Pre-k collaboratives are also given funding to enhance the equipment in collaborative classrooms. Teachers in the classrooms can purchase items that are needed to increase scores. The additional funds for equipment can help the classroom meet the indicators on the rating scale.

\section{Activities}

There was a significant difference on the Activities subscale for pre-k collaborative classrooms and non-collaborative classrooms. Pre-k collaborative classrooms scored significantly higher on this subscale than non-collaborative classrooms. Due to regulations of the WV State Department of Education, lesson plans of pre-k teachers in collaborative classrooms are reviewed by the respective County Department of Education. Collaborative teachers must use the West Virginia Content Standards and each county has a lesson plan protocol to follow that meets the specifications of the WV Public Policy 2525. This structural aspect fits within Bronfenbrenner's macrosystem as it relates to the pre- $\mathrm{k}$ state requirements. Pre-k noncollaboratives are not under the jurisdiction of WV Public Policy 2525 and if the lesson plans are reviewed by internal staff at the center. In general, the staffs at child care centers do not have as high of academic constraints for their teachers. It must be noted 
that a director of WV child care center does not require a degree beyond an associative degree. In fact, in a small center the director only needs 12 college credits. There is more professional monitoring in pre-k collaborative classrooms.

Other structural factors that have a major affect on this subscale are teacher education and teacher-child ratios. Teachers with higher education are more likely to developed developmentally appropriate activities, have a greater understanding of teaching tools such as scaffolding the child's learning and the project approach, and integrating numerous curriculum areas into child and teacher-directed activities. Also, having a positive teacher-child ratio allows for more rich interactions between child and teacher, so there are more opportunities for scaffolding and learning experiences.

Because collaborative classrooms are evaluated by the ECERS-R regularly, the teachers may have a greater understanding of what materials and activities should be accessible during free play, and how many minutes each child should have exposure to those materials. Again, this finding that pre-k collaborative had higher scores on the subset of activities follows previous findings that structural quality such as teacher qualifications provides a framework and is linked to process quality which includes program activities (Bordin et al.,2000; Cryer et al., 1999). With higher levels of education, teachers are more likely to provide better language development, learning activities, and have better knowledge of basic care (Cryer, 1999; Norris, 2001).

\section{Program Structure}

Pre-k collaborative classrooms scored higher than non-collaborative classrooms on the subscale of Program Structure. There was a significant difference between the two types of classrooms on this subscale. Pre-k collaboratives are required to have daily 
schedules in each classroom as well as the proper amount of free play time in the schedule due to structural factors that require classrooms be evaluated every three years by the ECERS-R. Pre-k collaboratives must follow the requirements for the formula specified in the ECERS-R for the number of minutes of free play. In addition, the free play time must be in the displayed schedule. Furthermore, West Virginia Department of Education (2012) requires pre-k collaborative programs to offer different activities (such as science activities/math materials) for a certain amount of time throughout the day based on program length. This provides a base for daily schedule that improves the process quality of the pre-k collaborative classrooms.

Pre-k collaborative classrooms also have special services for children with special needs that are put in place due to structural factors. In fact, three year old children who have an Individualized Education Plan (IEP) can attend the four- year -old pre-k collaborative classroom (Department of Education, 2012). Individual Education Plans (IEPs) are required for children who have special needs in pre-k collaboratives. The IEP meetings are attended by myriad of specialists who discuss the services needed to help the child. Because the pre-k collaborative in child cares have more monitoring and teachers with higher levels of education, children who need special service would more likely be identified. Once again, this study found more quality factors in the pre-k collaborative classrooms which are under the review of two State entities. These are similar results that the Cost, Quality and Child Outcomes in Child Care Centers (1995) study found that with more regulations the quality level is better than in their classrooms with less stringent regulations. 


\section{Total Scores}

The total ECERS-R score was higher in the pre-k collaborative classrooms than the non-collaborative classrooms. This finding agrees with many research studies (Phillipsen, et al., 1997; Cryer et al., 1999; Bordin, et al., 2000; Barnett, 2003; Smith, 2005; Early, et al., 2006; Bogard, et al., 2008) that more regulations result in higher quality classrooms. Pre-k collaborative classrooms have greater structural quality as they must adhere to the DHHR licensing and WV Department of Education Policy 2525 requirements. These additional structural requirements (teacher education, teacher child ratio, higher pay), that collaborative classrooms must adhere to seem to have strengthened process quality (environmental design, activities) on the ECERS-R. This gives light to the total picture of the macrosystem (structural quality) affecting the microsystem level (process quality). It must be stated that The West Virginia Kids Count (2012) reported that nearly $60 \%$ of child care workers had no training in caring for children.

\section{Personal Care Routines}

Average scores for personal care routines for collaborative and non-collaboratives were below the threshold for a minimal quality rating. Cryer and colleagues (2003) also found personal care routines typically receive low scores on the ECERS-R. It is well known that this is an area that needs much improvement. This finding is similar to the findings in the study by Warash, Markstrom and Lucci (2006) where low scores were found on the ECERS-R but improved when the ECERS-R was used as a training tool. Low scores on the personal care routine can be contributed to the strict requirements on 
the ECERS-R. Even though the indicators are quite important, it is difficult to achieve all the indicators when there are only two teachers to complete all these tasks. For example, the hand washing steps require children to use soap and rub hands together for 20 seconds. In a classroom of 20 children, a few children slipping on this bring the score down. Sanitizing a table requires using disinfect of a bleach and water formula where it sets on table for two minutes before placing food items on the table. If the same sink is used for both toileting and food related routines, it must be properly sanitized by spraying sink and faucets with a bleach solution after toileting. Sinks and toilets should also be child sized to assist in promoting self help skills. These are difficult requirements to meet completely and scores are lowered if not met perfectly.

\section{Language-Reasoning}

Collaborative classrooms had a higher mean score than non-collaborative classrooms but it was not a significant difference. Pre-k collaborative classrooms had a mean score on the Language-Reasoning subscale slightly above five which is considered a good rating. Non-collaborative classrooms received a score just below five. The items in this subscale include typical things you may find in schools and child care facilities, such as a wide selection of books, staff reading books to children. Other materials that encourage communication are included such as child dictation on artwork, puppets, flannel board, and small figures in the block area. Instances of staff talking about logical relationships such as the daily schedule of the class are included in this indicator. This is a requirement in all preschool classrooms. The higher mean score could be due the structural factor of greater teacher education. Teachers with higher education have a greater understanding of how to encourage communication and what materials are 
effective at doing so. More highly educated staff may be more aware of the benefits of talking about logical relationships and other ways to develop language.

\section{Interaction}

There was not a significant difference between the mean scores for the Interaction subscale for pre-k collaborative and non-collaborative classrooms. Pre-k collaborative classrooms had a slightly higher mean in this subscale, but both classrooms were above 5, a rating that is considered good. One explanation for the finding of no difference could be due to the structural factors that both collaborative and non-collaborative classrooms must follow West Virginia Department of Health and Human Resources (WVDHHR) regulations. Two of the items within this subscale deal with proper staff supervision which is strictly enforced by WVDHHR. Child care centers go through WVDHHR licensing every two years and staff supervision with the required number of staff is a very tangible indicator to calculate. Both pre-k collaborative programs and non-collaborative programs that are in child care settings must adhere to the regulations of WVDHHR with regard to teacher-child ratio. According to WVDHHR, a four year old classroom must have one qualified staff member for every 12 children, with no more than 24 children in a group (West Virginia Department of Health and Human Resources, 2009). Pre-k collaborative programs, however, can have no more than 20 children in a group according to the West Virginia Department of Education (2012). Pre-k collaborative programs did have a higher mean, though it was not significant. This can be due to the lower amount of children allowed per group. 


\section{Parents and Staff}

Pre-k collaborative classrooms had a higher mean score on the subscale Parents and Staff than non-collaborative classrooms, however it was not significant. West Virginia has mandated that child care teachers have 15 hours of registered training each year under the WV State Training and Registry System (WV S.T.A.R.S.; West Virginia Department of Health and Human Resources, 2009). It is required that all staff in child care facilities are registered with the WV S.T.A.R.S. and the child care centers allow these trainings to be available to their staff. Trainings held through the WV S.T.A.R.S. fall under many core knowledge areas including family and community, professionalism, and program management. This factor of structural quality could be benefitting the noncollaborative classroom with regard to Parents and Staff subscale. The collaborative pre-k classrooms again must be evaluated by the ECERS-R every three years so the teachers are familiar with the requirements of the ECERS-R on this subscale (Department of Education, 2012).

\section{Summary}

The findings of this study supports past research that classrooms with more regulations supports higher quality care. Collaborative classrooms follow the regulations of WVDHHR and WV Policy 2525 of the State Department of Education. Three of the ECERS-R subscales were significantly higher in collaborative classrooms. These differences were found in Space and Furnishings, Activities, and Program Structure. There was also a significant difference in the overall scores of the collaborative and non collaborative classrooms. Regulations from the WVDHHR and WV Public Policy 2525 of the State Department of Education are put into practice in order to control for 
classroom quality. With pre-k collaboratives responding to regulations from two entities, the quality in these classrooms tends to be higher.

\section{Limitations and Recommendations}

One limitation of the study is the low number of collaborative classrooms in comparison to the number of non-collaborative classrooms. The current study had 36 prek collaborative programs participating and 136 non-collaborative pre-k classrooms. However, it is the consensus of the WVDHHR licensing that the majority of pre-k classrooms are non-collaboratives. A larger sample may have produced stronger results.

It is important to note that the centers who take the initiative to become a pre-k collaborative may be of higher quality. These centers are willing to complete the extra work and adapt their classrooms to fall into the regulations of the Department of Education for pre-k collaboratives. The administration and staff of the centers that are willing to additionally affiliate themselves with the Department of Education are more likely to do what is necessary to be sure classrooms are of higher quality. Centers who take the initiative to be a collaborative are likely to be more accepting of higher standards.

With regard to recommendations, the ECERS-R subscale scores received in both pre-k collaborative and non-collaborative classrooms were low, with the overall score not even breaking the standard for "good" quality. Looking at the subscales individually, it is apparent that many classrooms struggle in the same areas, receiving very low scores. In a study completed by Warash and colleagues (2005), it was shown that environmental rating scores improved significantly after classroom teachers had been trained on the ECERS-R. Based on these findings, it can be implied that training classroom teachers 
regularly on this topic could improve the quality of child care in their classroom and in turn, throughout West Virginia.

\section{Conclusion}

Quality early childhood experiences are certainly in the mainstream of America right now. Nationally it is a topic that has hit the forefront in all political avenues. Many states are reviewing ways to start or enhance their early childhood programs. West Virginia is not immune to this topic. Currently, Senate WV Bill 359 is the legislation to increase West Virginia's pre-k classrooms. If this bill passes, counties must offer some of their pre-k classrooms as all day classrooms. It is still not mandated that all four-yearolds attend. Longer hours of pre-k does not equate to quality. Rather, it is the factors that have been addressed in this paper that seem to affect quality. Factors such as more defined professional regulations and more education for the pre-k teachers are ones that have re-occurred in the literature. 


\section{References}

Barnas, M. V., \& Cummings, E. M. (1994). Caregiver stability and toddler's attachmentrelated behavior towards caregivers in day care. Infant Behavior and Development, 17, 141-147.

Barnett, S. (2003). Better teachers, better preschools: Student achievement linked to teachers qualifications. Preschool Policy Matters, 2, 1-12.

Barnett, W.S., Jung, K., Youn, M., Frede, E., Abbott (2013). Preschool Program Longitudinal Effects Study: Fifth Grade Follow-Up. Rutgers, NJ: National Institute for Early Education Research, 1-34. Retrieved from http://nieer.org/sites/nieer/files/APPLES\%205th\%20Grade.pdf

Beller, E.K. (1972). Impact of early education on disadvantaged children. A Report on Longitudinal Evaluations of Preschool Programs. Office of Child Development, $1-85$.

Bogard, K., Traylor, F., \& Takanishi, R. (2008). Teacher education and pk outcomes: Are we asking the right questions? Early Childhood Research Quarterly, 23(1), 1-6. Retrieved from: http://dx.doi.org/10.1016/j.ecresq.2007.08.002

Bordin, J., Machida, S., \& Varnell, H. (2000). The relation of quality indicators to provider knowledge of child development in family child care homes. Child \& Youth Care Forum, 29(5), 323-341.

Brendtro, L. K. (2006). The Vision of Urie Bronfenbrenner: Adults who are crazy about kids. Reclaiming Children \& Youth, 15(3), 162-166.

Retrieved from: http://ad4tq3gq5x.search.serialssolutions.com/?ctx_ver=Z39.882004\&ctx_enc=info $\% 3$ Aofi $\% 2$ Fenc\%3AUTF8\&rfr_id=info:sid/summon.serialss 
olutions.com\&rft_val_fmt=info:ofi/fmt:kev:mtx:journal\&rft.genre=article\&rft.atit le $=$ The + Vision + of + Urie + Bronfenbrenner $\% 3 \mathrm{~A}+$ Adults + Who + Are + Crazy + about + Kids\&rft.jtitle= $=$ Reclaiming + Children + and + Youth $\% 3 \mathrm{~A}+$ The + Journal + of + Strengt hbased + Interventions\&rft.au $=$ Brendtro $\% 2 C+$ Larry + K\&rft.date $=2006 \& r f t . p u b=C$ ompassion + Publishing + LTD\&rft.issn $=10895701 \&$ rft.volume $=15 \&$ rft.issue $=3 \&$ rf t.spage $=162 \&$ rft.epage $=166 \& r f t . e x t e r n a l D o c I D=E J 745917$

Bronfenbrenner, U. (1994). Ecological models of human development. In J. Bayne, C. Gardner \& R. Rothschild (Eds.), Readings on the development of children (4 ed., pp. 3-8). New York, NY: Worth Publishers.

Bronfenbrenner, U., \& Morris, P.A. (1998). The ecology of developmental processes. Handbook of Child Psychology, 1(5), 993-1028.

Burchinal, M., Howes, C., \& Kontos, S. (2002). Structural predictors of child care quality in Child care homes. Early Childhood Research Quarterly, 17(1), 87.

Burchinal, M., Vandergrift, N., Pianta, R., Mashburn, A. (2010) Threshold analysis of association between child care quality and child outcomes for low-income children in pre-kindergarten programs Early Childhood Research Quarterly, 25 (2),166-176. doi: 10.1016/j.ecresq.2009.10.004

Campbell, F. A., Pungello, E. P., Burchinal, M., Kainz, K., Pan, Y., Wasik, B. H., Barbarin, O. A., Sparling, J.J., Ramey, C. T. (2012). Adult outcomes as a function of an early childhood educational program: An Abecedarian Project follow-up. Developmental Psychology, 48(4), 1033-1043. doi:10.1037/a0026644 
Clarke-Stewart, K., Vandell, D., Burchinal, M., O’Brien, M., \& McCartney, K. (2002). Do regulable features of child-care homes affect children's development? Early Childhood Research Quarterly, 17(1), 52-86.

Cooke, J. (2007). Children reap significant benefits when exposed to quality early childhood education experiences. Reading Today, 25(1), 18-18.

Cost, Quality, and Child Outcomes Study Team (1995). Cost, quality, and child outcomes in child care centers, Public Report. Denver: Economics Department, University of Colorado-Denver.

Cryer, D. (1999). Defining and Assessing Early Childhood Program Quality. Annals of the American Academy of Political and Social Science, 563, 39-55. Retrieved from: http://www.jstor.org/stable/1048939

Cryer, D., Harms, T., \& Riley, C. (2003). All about the ecers-r: A detailed guide in words in pictures. (pp. 1-440). Lewisville. NC: PACT House Publishing.

Cryer, D., \& Phillipsen, L. (1997). Quality details: A close-up look at child care program strengths and weaknesses. Young Children, 52(5), 51-61.

Cryer, D., Tietze, W., Burchinal, M., Leal, T., Palacios, J. (1999). Predicting process quality from structural quality in preschool programs: a cross-country comparison Early Childhood Research Quarterly, 14 (3), 339-361. Retrieved from: http://dx.doi.org/10.1016/S0885-2006(99)00017-4

West Virginia Department of Education. WV Department of Education, Office of Special Programs. (2012). Policy 2525: West Virginia's universal access to a quality early education system (23901). Retrieved from website: http://apps.sos.wv.gov/adlaw/csr/readfile.aspx?DocId=23901\&Format=PDF 
Derman-Sparks, L., \& the A.B.C. Task Force. (1989) Anti-bias curriculum: Tools for empowering young children. Washington, DC: NAEYC.

Dodge, D. T., Colker, L. J., \& Heroman, C. (2002). The Creative Curriculum: for Preschool. 4th Edition. Washington D.C., Teaching Strategies, Inc.

Early, D.M., Bryant, D.M., Pianta, R.C., Clifford, R.M., Burchinal, M.K., Ritchie, S., Howes, C., Barbarin, O. (2006) Are teachers' education, major, and credentials related to classroom quality and children's academic gains in prek? Early Childhood Research Quarterly, 21(2), 174-195.

Hamre, B. K. and Pianta, R. C. (2005), Can instructional and emotional support in the first-grade classroom make a difference for children at risk of school failure? Child Development, 76(5), 949-967. doi: 10.1111/j.1467-8624.2005.00889.x

Harms, T., Clifford R. M., \& Cryer, D. (2005) The Early Childhood Environment Rating Scale-Revised. New York, NY: Teachers College Press.

Head Start. U.S. Department of Health and Human Services, Administration for children and families. (2007). Improving head start for school readiness act of 2007 (42 USC 9801). Retrieved from website: http://eclkc.ohs.acf.hhs.gov/hslc/standards/Head Start Act/HS_ACT_PL_110134.pdf

Howes, C., Burchinal, M., Pianta, R., Bryant, D., Early, D., Clifford , R., \& Barbarin, O. (2008). Ready to learn? Children's pre-academic achievement in pre-kindergarten programs. Early Childhood Research Quarterly, 23(1), 27-50. doi:

10.1016/j.ecresq.2007.05.002 
Howes, C. \& Ritchie, S. (2002). A Matter of Trust: Connecting Teachers and Learners in the Early Childhood Classrooms, New York, NY: Teachers College Press.

Gray, S. W., \& Klaus, R.A. (1970). The early training project: The seventh year report. Child Development, 41(4), 909-924.

Lanigan, J. D. (2011). Family child care providers' perspectives regarding effective professional development and their role in the child care system: A qualitative study. Early Childhood Education Journal, 38(6), 399-409.

Morrissey, T.W. (2007). Family child care in the United States. Child Care \& Early Education Research Connections. Retrieved from http://www.researchconnections.org/childcare/resources/11683/pdf

National Association of Child Care Resource \& Referral Agencies. (2010) Parents and the High Cost of Child Care: 2010 Retrieved from: http://eyeonkids.ca/docs/files/cost_report_073010-final.pdf

National Institute of Child Health and Human Development, Early Child Care Research Network. (2000). Characteristics and quality of child care for toddlers and preschoolers. Applied Developmental Science, 4, 116-135.

Norris, D. J. (2001). Quality of care offered by providers with differential patterns of workshop participation. Child \& Youth Care Forum, 30(2), 111-121.

Peisner-Feinberg, E. S., \& Burchinal, M. R. (1997). Relations between preschool children's child-care experiences and concurrent development: The cost, quality, and outcomes study. Merrill-Palmer Quarterly, 43(3), 451-477. 
Phillips, D. A., Mekos, D., Scarr, S., McCartney, K., \& Abbott-Shim, M. (2000). Within and beyond the classroom door: Assessing quality in child care centers. Early Childhood Research Quarterly, 15(4), 475-496.

Phillipsen, L. C., Burchinal, M. R., Howes, C., \& Cryer, D. (1997). The prediction of process quality from structural feature of child care. Early Childhood Research Quarterly, 12(3), 281-303.

Pianta, Robert. (2000). Enhancing relationships between children and teachers. Washington, DC: American Psychological Association.

Pianta, R. C., La Paro, K. M., \& Hamre, B. K. (2008). The classroom assessment scoring system. manual, pre-k. Baltimore, MD: Brookes.

Raikes, H., Raikes, H. H., \& Wilcox, B. (2005). Regulation, subsidy receipt and provider characteristics: What predicts quality in child care homes? Early Childhood Research Quarterly, 20(2), 164-184.

Ramey, C. T., \& Ramey, S. L. (1998). Early intervention and early experience. Applications of Developmental Science, 53(2), 109-120. doi: 10.1037/0003066X.53.2.109

Scarr, S., Eisenberg, M. \& Deater-Deckard, K. (1994). Measurement of quality in child care centers. Early Childhood Research Quarterly, 9, 131-151.

Smith, W. E. (2005) Structural characteristics that predict quality in preschool-age classrooms in child care centers (Unpublished Doctoral Dissertation). University of Pittsburgh, Pittsburgh, Pennsylvania.

U.S. Department of Education. (2011). Race to the top fund. Federal Register, 76(176), 56183-56188. 
Warash, B., (2011). Quality rating and improvement for West Virginia child care.

Unpublished final report, Department of Technology, Learning and Culture, West Virginia University, Morgantown, West Virginia.

Warash, B., Markstrom, C., \& Lucci, B. (2005). The Early Childhood Environmental Rating Scale-Revised as a tool to improve child care centers. Education, 126(2), $240-250$.

West Virginia Department of Education, Office of Early Learning. (2012). Building intentionality in a collaborative design and implementation for West Virginia universal pre-k. Retrieved from website: http://static.k12.wv.us/oel/docs/WV Universal PreK Overview_4.2012.pdf

West Virginia Department of Health and Human Resources (2009). Child care centers licensing. Retrieved from: http://www.wvdhhr.org/bcf/ece/earlycare/documents/2009ChildCareCenterRegul ationWeb.pdf

West Virginia KIDS COUNT. (2012, February 15). 2011 WV kids count data book asks: "is WV a great place to be a kid?". Retrieved from http://www.wvkidscount.org/2011-wv-kids-count-data-book-asks-wv-great-placebe-kid

Weimar, D. (1967). Preschool intervention; a preliminary report of the Perry preschool project. Ann Arbor, MI: Campus Publishers.

Whitebook, M., Howes, C., \& Phillips, D.A., (1989). Who Cares? Child Care teachers and the quality of care in America. Oakland, CA: Child Care Employee Project. 